\title{
Preparation of Activated Carbon from the Wood of Paulownia tomentosa as an Efficient Adsorbent for the Removal of Acid Red 4 and Methylene Blue Present in Wastewater
}

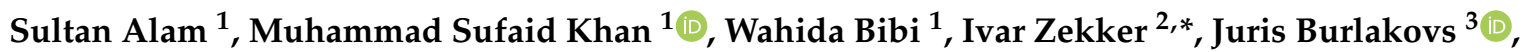 \\ Makarand M. Ghangrekar ${ }^{4}{ }^{\infty}$, Gourav Dhar Bhowmick ${ }^{4}$, Anna Kallistova ${ }^{5}$, Nikolai Pimenov ${ }^{5}$ and \\ Muhammad Zahoor ${ }^{6, *}$ (1)
}

check for updates

Citation: Alam, S.; Khan, M.S.; Bibi, W.; Zekker, I.; Burlakovs, J.; Ghangrekar, M.M.; Bhowmick, G.D.; Kallistova, A.; Pimenov, N.; Zahoor, M. Preparation of Activated Carbon from the Wood of Paulownia tomentosa as an Efficient Adsorbent for the Removal of Acid Red 4 and Methylene Blue Present in Wastewater. Water 2021, 13, 1453. https://doi.org/10.3390/w13111453

Academic Editors: Didier Orange and Xanel Vecino

Received: 20 April 2021

Accepted: 19 May 2021

Published: 22 May 2021

Publisher's Note: MDPI stays neutral with regard to jurisdictional claims in published maps and institutional affiliations.

Copyright: () 2021 by the authors. Licensee MDPI, Basel, Switzerland. This article is an open access article distributed under the terms and conditions of the Creative Commons Attribution (CC BY) license (https:// creativecommons.org/licenses/by/ $4.0 /)$.
1 Department of Chemistry, University of Malakand, Chakdara Dir Lower 18800, KPK, Pakistan; dr.sultanalam@yahoo.com (S.A.); sufaidkhan1984@gmail.com (M.S.K.); ipervezkhan@gmail.com (W.B.)

2 Institute of Chemistry, University of Tartu, 14a Ravila St., 50411 Tartu, Estonia

3 Institute of Forestry and Rural Engineering, Estonian University of Life Sciences, 5 Kreutzwaldi St., 51014 Tartu, Estonia; Juris.burlakovs@emu.ee

4 School of Environmental Science and Engineering, Indian Institute of Technology Kharagpur, Kharagpur 721302, India; ghangrekar@civil.iitkgp.ac.in (M.M.G.); gourav.db@gmail.com (G.D.B.)

5 Winogradsky Institute of Microbiology, Research Centre of Biotechnology of the Russian Academy of Sciences, Leninsky Prospect, 33, Build. 2, 119071 Moscow, Russia; kallistoanna@mail.ru (A.K.); npimenov@mail.ru (N.P.)

6 Department of Biochemistry, University of Malakand, Chakdara Dir Lower 11800, KPK, Pakistan

* Correspondence: ivar.zekker@ut.ee (I.Z.); mohammadzahoorus@yahoo.com (M.Z.)

\begin{abstract}
Paulownia tomentosa, a woody plant that is widely found in Pakistan and in other regions of the world, was used as a raw material to prepare activated carbon using chemical and physical activation methods. Adsorption of the dyes- acid red 4 and methylene blue onto the prepared activated carbon were analyzed by batch experiments. The impacts of different adsorption parameters such as $\mathrm{pH}$, temperature, contact time, initial dye concentration and adsorbent dosage were also evaluated. Equilibrium data were fitted into various isotherm models such as: Langmuir, Temkin and Freundlich. High regression values were achieved with Langmuir isotherm model. Different kinetic adsorption models such as pseudo-first-order, pseudo-second-order and intra-particle diffusion model models were applied. The adsorption kinetics was found to be best-fitted into pseudo-secondorder kinetic model. The optimum $\mathrm{pH}$ for acid red 4 was around 1 while for methylene blue it was 8 . The optimum adsorbent dosage was $0.3 \mathrm{~g}$ for both dyes used. The activation energy $\left(\mathrm{E}_{\mathrm{a}}\right)$ values were 30.57 and $3.712 \mathrm{~kJ} / \mathrm{mol}$, respectively for acid red 4 and methylene blue while the enthalpy $(\Delta \mathrm{H})$ and entropy $(\Delta \mathrm{S})$ values were correspondingly as $24.88 / 1.1927 \mathrm{~kJ} / \mathrm{mol}$ and $-2843.32 /-0.329 \mathrm{~J} \cdot \mathrm{mol} / \mathrm{K}$ for the mentioned dyes. The experimental result showed that the prepared activated carbon was the best in the removal of acid red 4 and methylene blue from aqueous media and therefore, could be preferably used as cheap adsorbent in wastewater treatment.
\end{abstract}

Keywords: Paulownia tomentosa; activated carbon; acid red 4; methylene blue; equilibrium data

\section{Introduction}

The requirement of clean water for drinking and other purposes is a direct need in this modern world as the available sources of drinking water are often contaminated with organic and inorganic pollutants throughout the world [1]. Rapid industrialization is the main cause of water pollution as water is used as solvent in different industrial processes. Textile industry is considered to be one of main contributor of water pollution as water is used there as solvent in fiber processing as well as to remove unnecessary chemicals from fabrics [2]. It is predicted that about 40-65 L of textile wastewater is produced per $\mathrm{kg}$ of cloth manufactured. These wastewaters are loaded with a number of synthetic 
chemicals, which are mostly incompatible for natural degradation processes leading to severe hazardous effects on environment and human health $[3,4]$. Color in water bodies is an unwanted product that leads to toxicity of water bodies apart from interferences in photosynthesis process [5,6]. Today, more than 3000 dyes are being used in the textile industries $[7,8]$. Synthetic colors are resolute mixtures having general applications in various areas such as in: paper, plastic and textile industries, etc. [9]. Acid red 4 is an acidic dye, which is used in dyeing nylon, wool, silk, paper, leather, and in the production of inks [10]. Acidic dyes are highly carcinogenic and can cause dysfunctions in many human body organs like kidneys, brain, liver, reproductive system and nervous system [11]; hence, the removal of these dyes from wastewater and water bodies is essential due to their adverse effects on environment [12].

Different wastewater treatment processes, like coagulation, flocculation, biodegradation, adsorption, and oxidation, are used to remove color residues from water [13]. None of them is $100 \%$ efficient, however, among them adsorption is a more effective process [14]. The significant benefit of adsorption for the control of water contamination is its low starting cost, straightforwardness and simple recovery of the adsorbent and adsorbate materials [15]. A number of adsorbents are used, however, among them activated carbon (AC) is preferably used due to its high surface area and because the fact that it can be prepared from low- cost raw materials [16]. Plant waste materials may offer an inexpensive source for their use in the AC production. These materials after carbonization and activation, can attain a high surface area ranging from $300-1200 \mathrm{~m}^{2} / \mathrm{g}$ [17]. Different plants waste biomass has been converted into activated carbon and have been used to remove different organic and inorganic pollutants from wastewaters.

Paulownia tomentosa is a woody plant found in Pakistan, China, India and other regions of the world that can grow over $30 \mathrm{~m}$ tall and has large heart- shaped leaves ranging from $10-20 \mathrm{~cm}$ in width and $15-30 \mathrm{~cm}$ in length with a $10-20 \mathrm{~cm}$ long petiole. The leaves are often preceded by pale violet to purple shaded tubular flowers similar to a foxglove. It is an ornamental plant grown in parks and gardens. The plant produces large quantities of biomass in terms of weathered twigs and leaves that needs to be utilized in a meaningful way [18-20].

In the connection with previous findings, the present study was designed to prepare activated carbon from Paulownia tomentosa using physiochemical activation methods. The prepared activated carbon was used as an adsorbent for the removal of the textile dyes acid red 4 (AR4) and methylene blue (MB) from water.

\section{Materials and Methods}

\subsection{Experimental}

$\mathrm{MB}$ and AR4 dyes were used as the adsorbates that were subjected to adsorption on activated carbon prepared from the wood of Paulownia tomentosa. Both dyes AR4 and MB were used without any further purification (purchased from Sigma Aldrich, Munich, Germany). Other chemicals used, such as $\mathrm{HCl}, \mathrm{HNO}_{3}$, and $\mathrm{NaOH}$ were also purchased from Sigma Aldrich. The chemical structures of the selected dyes and the compounds names, chemical formulae and solubility features are given in Figure 1a,b and Table 1 below.

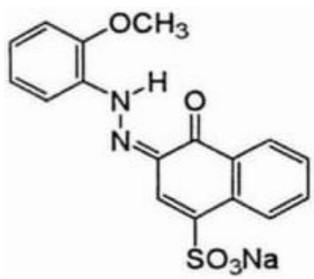

(a)

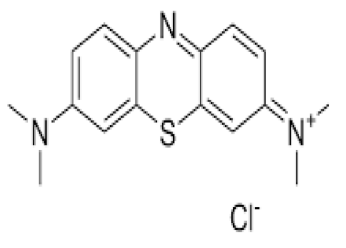

(b)

Figure 1. Chemical structures of: (a) Acid Red 4 (b) Methylene Blue. 
Table 1. Physiochemical properties of Acid Red 4 and Methylene Blue.

\begin{tabular}{|c|c|}
\hline \multicolumn{2}{|c|}{ Acid Red 4} \\
\hline Chemical Name & Acid Red 4 \\
\hline Molecular Formula & $\mathrm{C}_{17} \mathrm{H}_{13} \mathrm{~N}_{2} \mathrm{NaO}_{5} \mathrm{~S}$ \\
\hline Molecular Weight & $380.35 \mathrm{~g} / \mathrm{mol}$ \\
\hline$\lambda-\operatorname{Max}$ & $508 \mathrm{~nm}$ \\
\hline \multicolumn{2}{|c|}{ Methylene Blue } \\
\hline Chemical Name & Methylene Blue \\
\hline Molecular Formula & $\mathrm{C}_{16} \mathrm{H}_{18} \mathrm{CIN}_{3} \mathrm{~S}$ \\
\hline Molecular Weight & $319.9 \mathrm{~g} / \mathrm{mol}$ \\
\hline$\lambda-\operatorname{Max}$ & $665 \mathrm{~nm}$ \\
\hline Solubility & Soluble in Water \\
\hline
\end{tabular}

\subsection{Instrumentation}

The prepared adsorbent was characterized by a surface area analyzer (NOVA2200e, Quantachrome, Boynton Beach, FL, USA), scanning electron microscopy (SEM, JSM5910, JEOL, Tokyo, Japan) and EDX (INCA200/Oxford Instruments, Buckinghamshire, UK) at the University of Peshawar, Pakistan. The dye concentration was determined by measuring absorbance using a double beam UV-vis spectrophotometer (UV-1800, Shimadzu Scientific Instruments Inc, Tokyo, Japan) at a wavelength of 508 and $665 \mathrm{~nm}$ for AR4 and MB, respectively. Adsorption experiments were conducted in a thermostatic water- bath shaker. The $\mathrm{pH}$ measurements were carried out using $\mathrm{pH}$ meter.

\section{Surface Area Determination}

To calculate surface area, Brunauer-Emmett-Teller (BET)- $\mathrm{N}_{2}$ adsorption analysis were performed manometrically using the Quantachrome NOVA 2200e system at $-196^{\circ} \mathrm{C}$ and the relative pressure $\left(\mathrm{P} / \mathrm{P}_{\mathrm{o}}\right)$ range: $0.05-0.85$. BET equation was used to obtain the surface area. The Dubinin-Radushkevich (DR) method and the NovaWin2 data analysis software was used to obtained pore size distribution.

\subsection{Preparation of Activated Carbon}

Paulownia tomentosa wood was used as raw material for the preparation of activated carbon. It was collected from Peshawar, Pakistan. A schematic presentation of the experimental setup is given in Figure 2.

The wood was liberated from the outer shell and afterwards homogenized into small pieces. The pieces were then washed and afterwards held in a laboratory fume hood for $24 \mathrm{~h}$ for the removal of water. After drying, wood pieces carbonized in a furnace under a nitrogen atmosphere. The carbonized pieces were then crushed through a sifter (150-180 nm).

The following parameters were determined:

$$
\begin{gathered}
\mathrm{q}_{\mathrm{t}}=\frac{\mathrm{C}_{0}-\mathrm{C}_{\mathrm{t}}}{\mathrm{W}} \mathrm{V} \\
\% \mathrm{R}=\frac{\mathrm{C}_{0}-\mathrm{C}_{\mathrm{t}}}{\mathrm{C}_{0}} \times 100
\end{gathered}
$$

where, $\mathrm{q}_{\mathrm{t}}$ is the amount of dye adsorbed $(\mathrm{mg} / \mathrm{g}), \% \mathrm{R}$ is dye removal efficiency, $\mathrm{C}_{0}$ is the initial dye concentration $(\mathrm{mg} / \mathrm{L}), \mathrm{c}_{\mathrm{t}}$ is dye concentration after adsorption, $\mathrm{V}$ is the volume of dye solution $(\mathrm{mL})$, while $\mathrm{W}$ is the weight of adsorbent $(\mathrm{g})$. The calibration curves of the experimental measurements performed on the dyes are given Figure 3. 


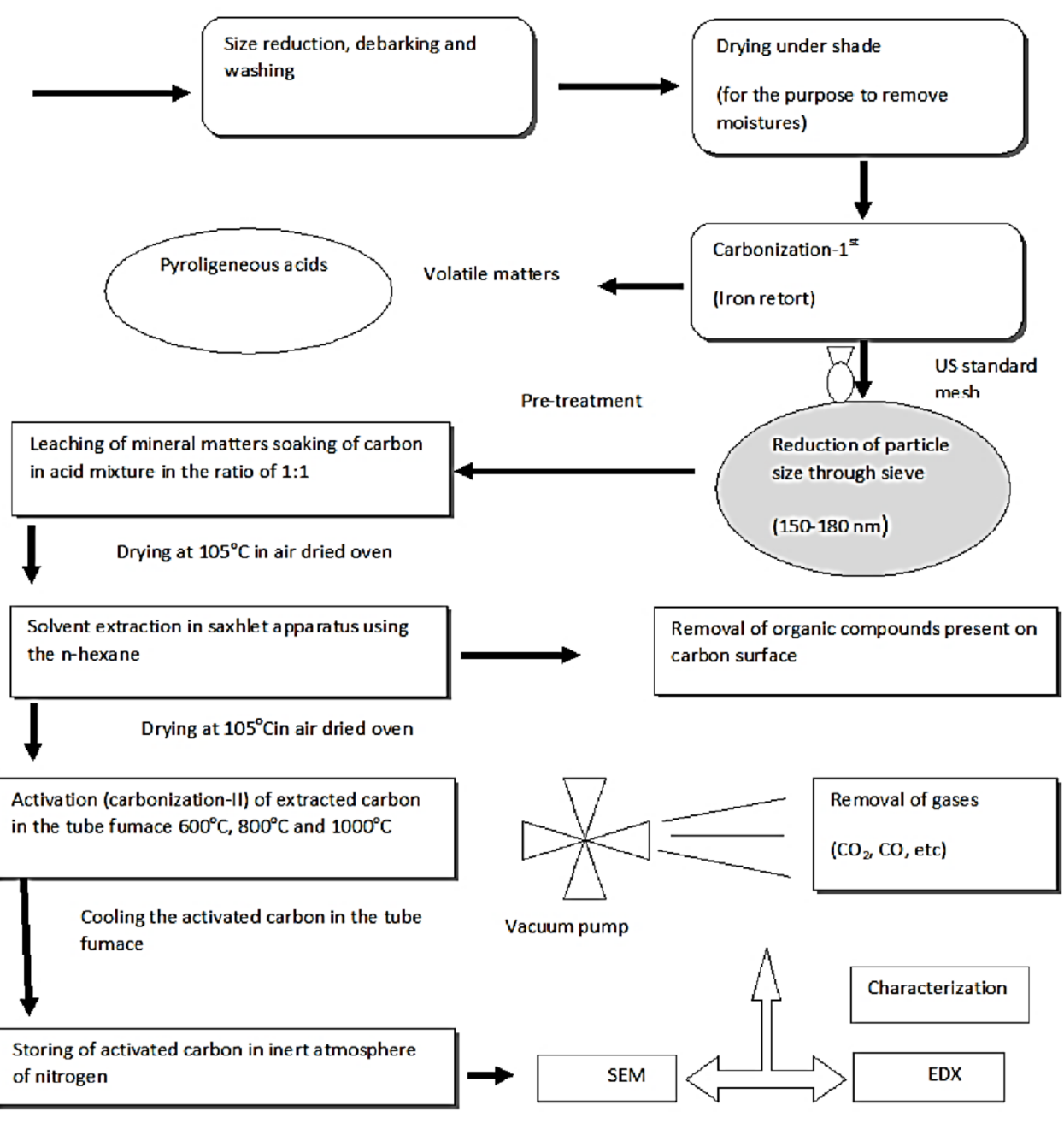

Figure 2. Preparation of activated carbon.

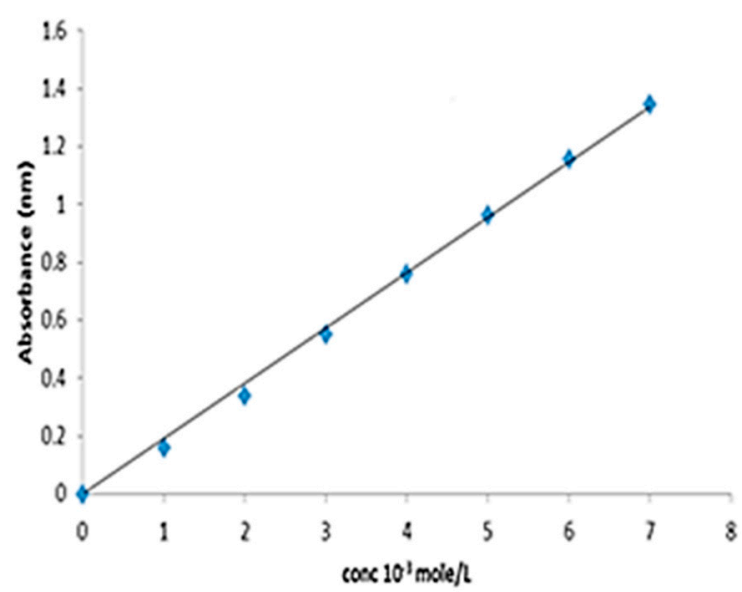

(a)

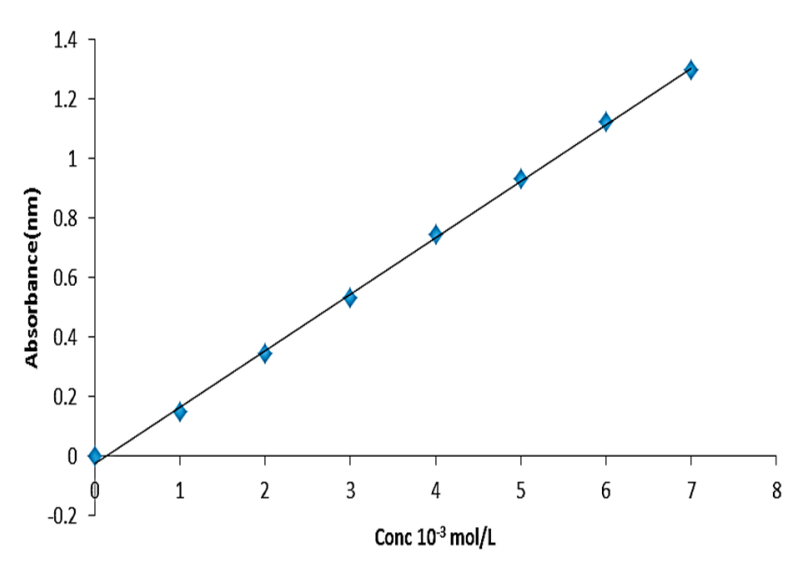

(b)

Figure 3. Calibration curves for (a) acid red 4 (b) methylene blue. 
Equilibrium adsorption experiments were conducted on a number of solutions ranging from $50-1000 \mathrm{mg} / \mathrm{L}$ by applying $0.3 \mathrm{~g}$ of prepared adsorbent. The $\mathrm{pH}$ of these samples was adjusted to 2 and 8 for AR4 and MB, respectively and after addition, the mixtures were stirred for one hour. The adsorbent was then separated from the mixture through filtration and remaining concentrations were determined using UV/VIS spectrophotometer. Kinetic studies were performed on $100 \mathrm{mg} / \mathrm{L}$ solutions, while remaining parameters were similar as mentioned above. Similarly, effects of adsorbent dosage, $\mathrm{pH}(2-12)$ and temperature were determined for $100 \mathrm{mg} / \mathrm{L}$ solutions keeping other parameters same as mentioned before.

\section{Results and Discussion}

\subsection{Characterization}

3.1.1. Scanning Electron Microscopy

The morphological studies of activated carbon were carried out using scanning electron microscopy (SEM) analysis. The SEM images at different magnifications are shown in Figure $4 \mathrm{a}-\mathrm{f}$. The micrographs show the rough surface of the prepared AC. On the surface there are irregular channels present for the adsorption of the dye and other pollutants.

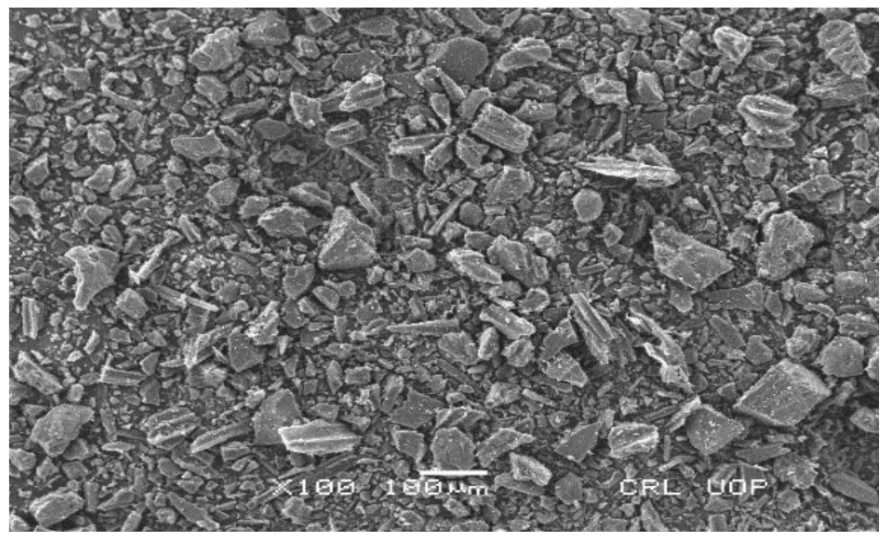

(a)

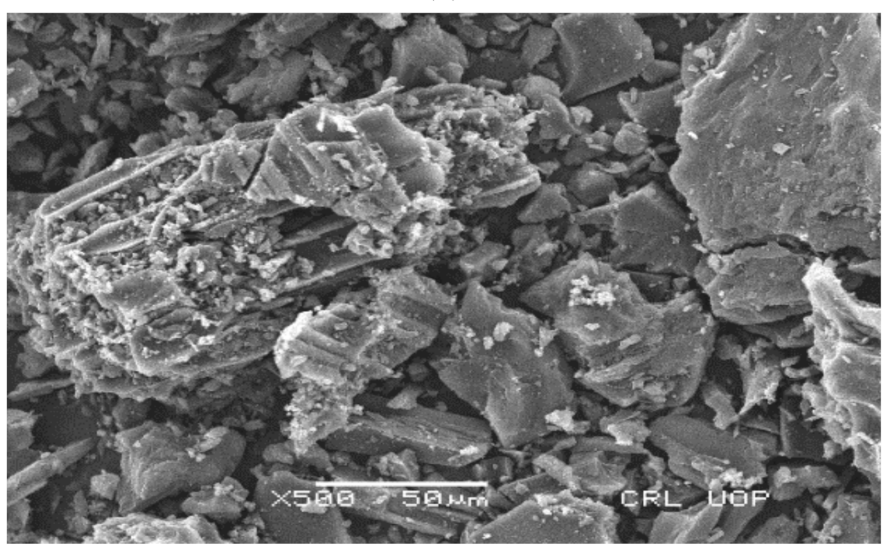

(c)

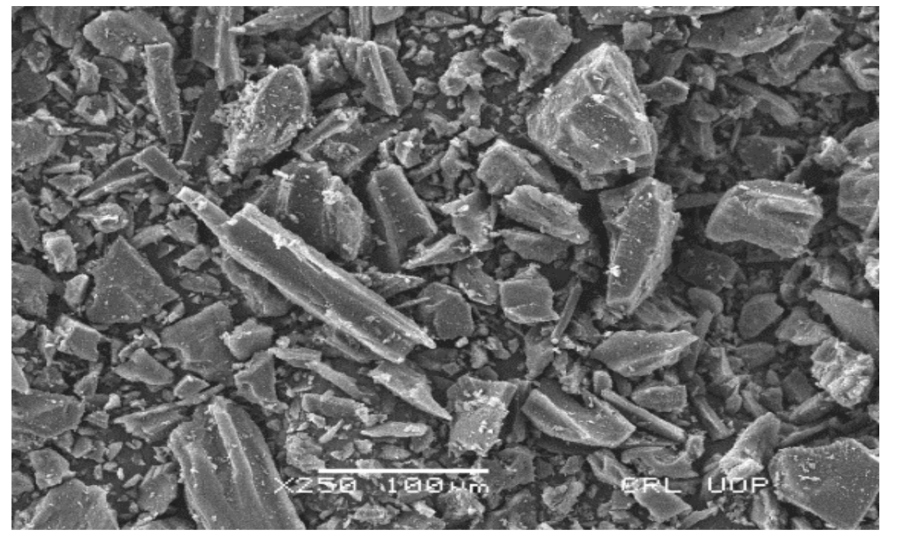

(b)

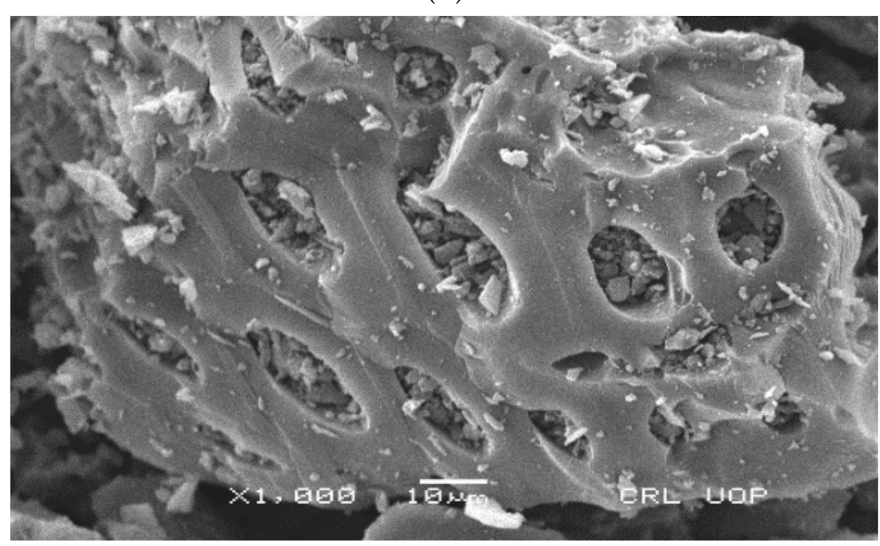

(d)

Figure 4. Cont. 


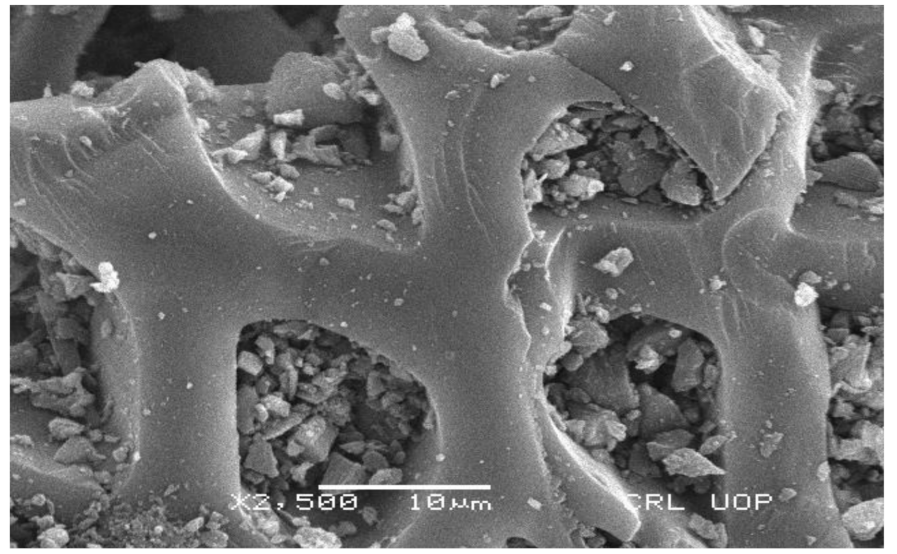

(e)

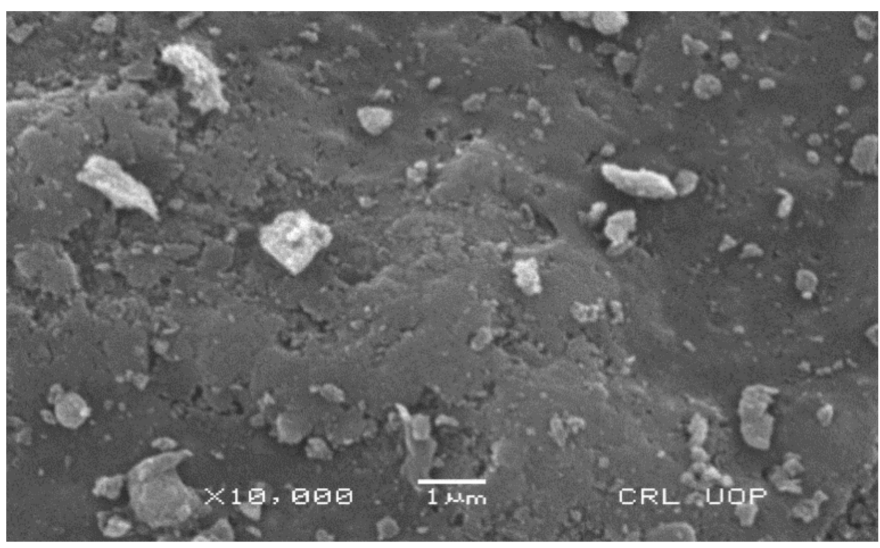

(f)

Figure 4. SEM images of prepared AC under various resolutions and magnifications: (a) $100 \times$ (b) $230 \times$ (c) $500 \times$ (d) $1000 \times$ (e) $2500 \times$ and (f) $10,000 \times$ magnifications.

\subsubsection{Energy Dispersed X-ray (EDX) Measurements of AC}

The EDX is an analytical technique used for the analysis of elemental composition and chemical characterization of samples. The EDX spectra of activated carbon showed that on the surface of all the AC samples, carbon and oxygen were mostly present. Carbon in the samples had a greater ratio than that of oxygen. The EDX spectra also showed the presence of other elements, such as calcium, magnesium, potassium and chlorine. The EDX spectra of $\mathrm{AC}$ is shown in Figure 5.

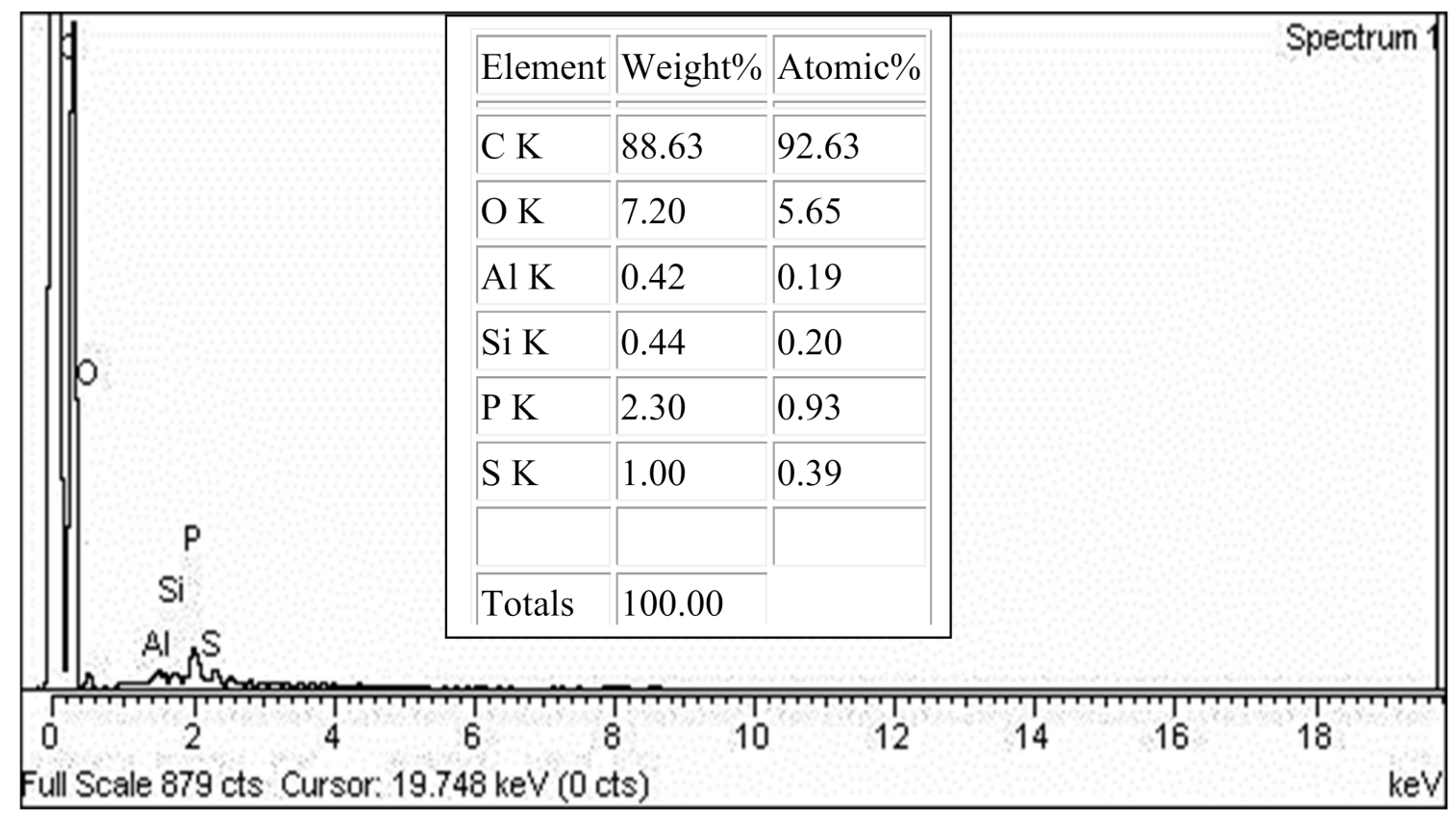

Figure 5. EDX analysis of prepared AC.

\subsection{Surface Area Determination}

Different techniques, such as BET, BJH, Langmuir and DR are used to calculate surface area of different samples. However, among them, the BET surface area $\left(\mathrm{m}^{2} / \mathrm{g}\right)$ analysis method is the most common and extensively used method. The BET equation is expressed as follows: 


$$
\frac{1}{\mathrm{~W}\left(\mathrm{P}_{0} / \mathrm{P}\right)-1}=\frac{1}{\mathrm{~W}_{\mathrm{m}} \mathrm{C}}+\frac{\mathrm{C}-1}{\mathrm{~W}_{\mathrm{m}} \mathrm{C}}\left(\frac{\mathrm{P}}{\mathrm{P}_{0}}\right)
$$

where: $\mathrm{W}=$ Weight of gas adsorbed, $\mathrm{P} / \mathrm{P}_{0}=$ Relative pressure, $\mathrm{W}_{\mathrm{m}}=$ weight of adsorbate constituting a monolayer coverage, $\mathrm{C}=$ related to the energy of adsorption in the first adsorbed layer. The values of calculated parameters are summarized in Table 2.

Table 2. Surface area and pore size AC derived from Paulownia tomentosa.

\begin{tabular}{ccccccccc}
\hline & \multicolumn{3}{c}{ Surface Area $\left(\mathbf{m}^{2} / \mathbf{g}\right)$} & \multicolumn{3}{c}{ Pore Size Distribution } \\
\hline \multicolumn{2}{c}{ Methods } & BJH Method & \multicolumn{2}{c}{ DR Method } \\
\hline BET & BJH & LSA & DR & $\begin{array}{c}\text { Pore volume } \\
\left(\mathrm{cm}^{3} / \mathrm{g}\right)\end{array}$ & $\begin{array}{c}\text { pore } \\
\text { diameter }(\AA)\end{array}$ & $\begin{array}{c}\text { Micropore } \\
\text { volume }\left(\mathrm{cm}^{3} / \mathrm{g}\right)\end{array}$ & $\begin{array}{c}\text { Average Pore } \\
\text { width }(\AA)\end{array}$ & $\begin{array}{c}\text { Ads. Energy } \\
(\mathrm{kJ} / \mathrm{mol})\end{array}$ \\
\hline 219.98 & 224.89 & 346.38 & 311.22 & 0.100 & 13.68 & 0.110 & 65.29 & 3.980 \\
\hline
\end{tabular}

\subsection{Dosage Effect on Removal of Acid Red 4 and Methylene Blue}

Dosage studies are important, because they determine the removal efficiency of a given adsorbent for a given pollutant and may also be used to predict the cost of the adsorbent per unit of solution to be treated. Hence, this effect was enumerated and it was found that the dye removal increased significantly as the adsorbent dosage was increased. The effect of dose of adsorbent on the percentage removal of AR4 and MB dyes is shown in Figure $6 \mathrm{a}, \mathrm{b}$. For both dyes the optimum dosage was found to be $0.3 \mathrm{~g}$, which was used in all the subsequent experiments.

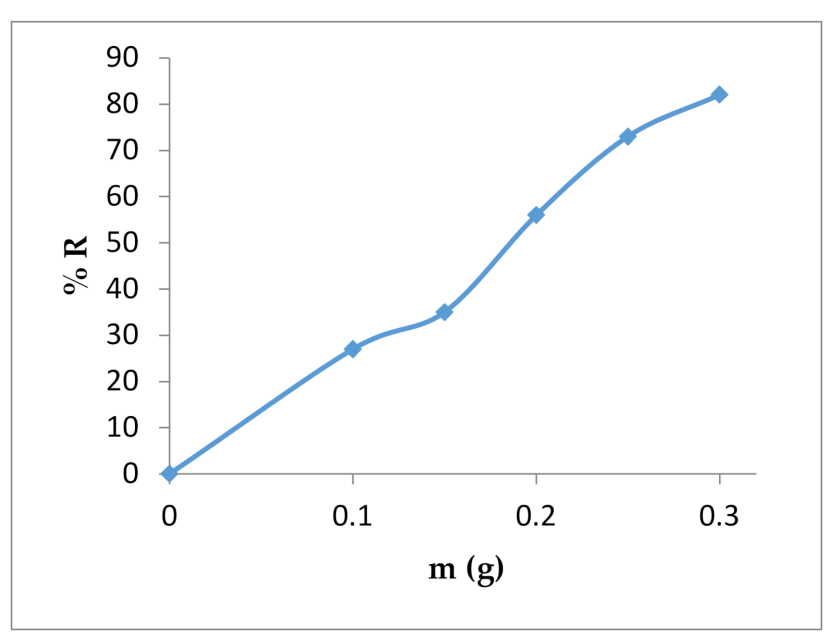

(a)

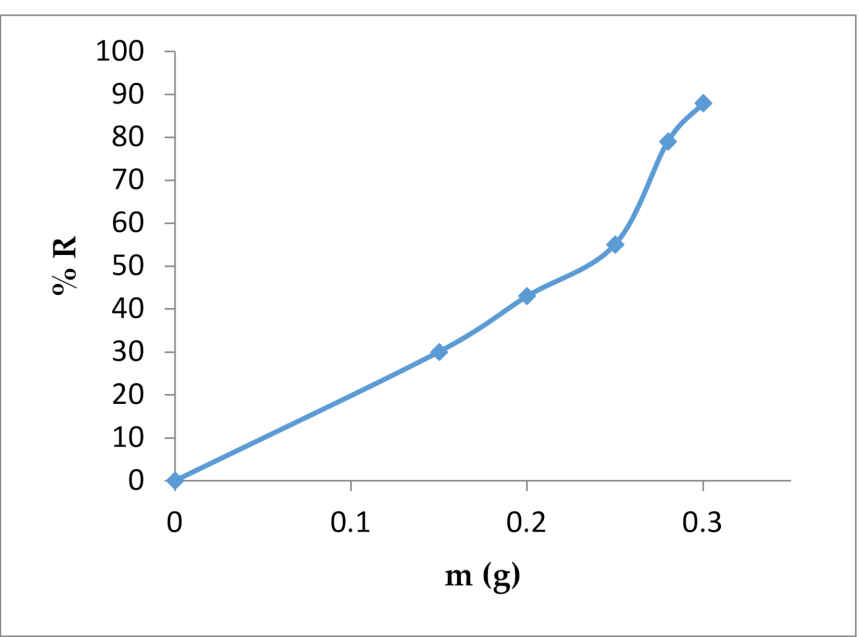

(b)

Figure 6. Effect of dosage on \% removal of: (a) acid red 4 (b) methylene blue.

\subsection{Effect of $\mathrm{pH}$ on Removal of Acid Red 4 and Methylene Blue}

The $\mathrm{pH}$ is an important parameter that affects the interactions between the adsorbent and adsorbate and the effect of $\mathrm{pH}$ on the adsorbate uptake may be highly, moderately or slightly significant depending on chemical structures of both dyes as it affects the degree of ionization. Figure $7 \mathrm{a}, \mathrm{b}$ show the effect of $\mathrm{pH}$ on adsorption of the selected dyes. The observed behaviours of the selected dyes towards the prepared adsorbent differ from each other, which is not surprising as one dye is negatively charged, while the other is positively charged and the tested $\mathrm{pH}$ ranges used were on acidic side for acid red 4, while methylene blue was in the basic form. For acid red the optimum $\mathrm{pH}$ for removal was around 1, while for methylene blue it was 8 . 


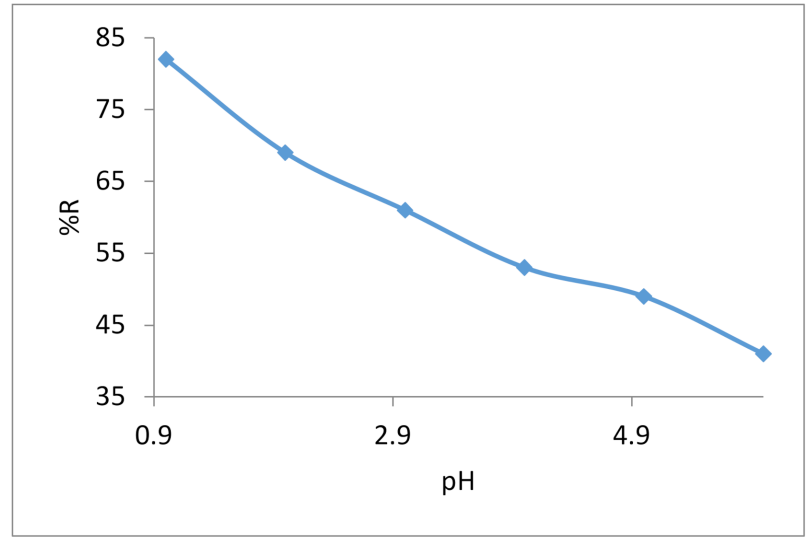

(a)

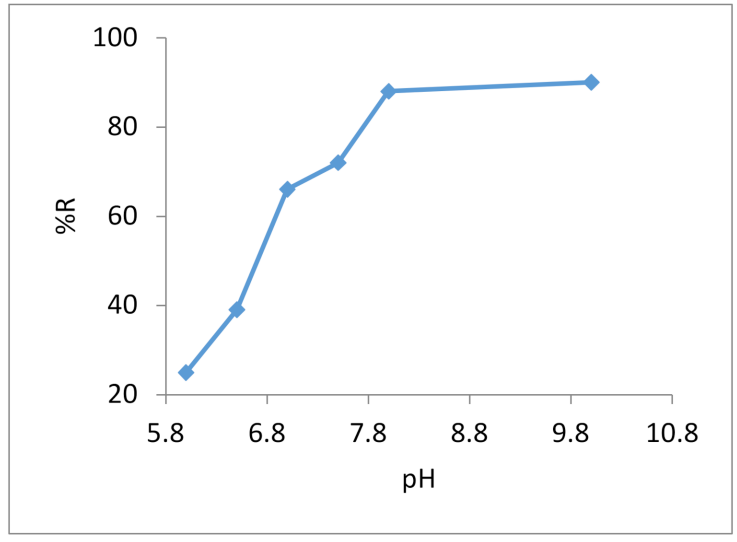

(b)

Figure 7. Effect of $\mathrm{pH}$ on \% removal of: (a) acid red 4 (b) methylene blue.

\subsection{Adsorption Kinetics}

It is necessary to consider the adsorption kinetics to understand the precise mechanism of the adsorption process. Apart from the determination of the adsorption mechanism, it is also helpful to understand the adsorbate-adsorbent interactions and adsorption characteristics. For this purpose, $0.3 \mathrm{~g}$ AC was added to series of $30 \mathrm{~mL}$ flasks containing 100 $\mathrm{mg} / \mathrm{L}$ AR4 and MB solutions. These flasks were shaken for different intervals of time at temperatures of 293, 303 and 313K.

The equilibrium times of AR4 and MB adsorption on the prepared AC are given in Figure $8 \mathrm{a}, \mathrm{b}$, respectively, at three different temperatures. The equilibrium was reached in 5 min. for both dyes. Initially, the adsorption sites available were high in numbers and as fast adsorption occurred, number of available adsorption sites decreased to a steady state.

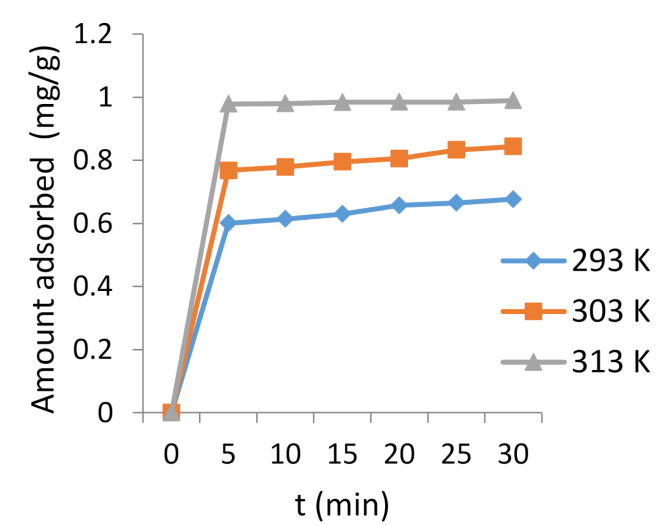

(a)

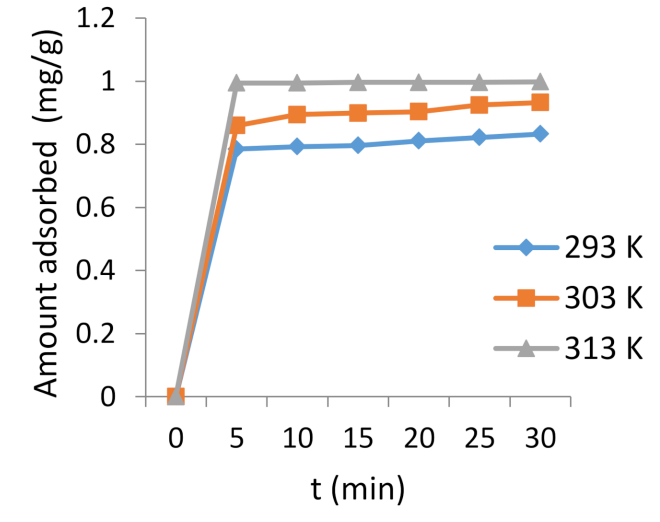

(b)

Figure 8. Adsorption kinetics for the adsorption of (a) AR4 (b) MB onto prepared AC.

A number of kinetics models were used to explain the kinetics of adsorption process (Figures 8 and 9). The different models applied in this study are given as follows [21-23]:

Pseudo-first order equation

$$
\log \left(q_{e}-q_{t}\right)=\log \left(q_{e}\right)-\frac{k_{1}}{2.303}
$$

Second-order Lagergren equation 


$$
\left(\frac{\mathrm{t}}{\mathrm{q}_{\mathrm{e}}}\right)=\frac{1}{\mathrm{k}_{2} \mathrm{q}_{\mathrm{e}}^{2}}+\frac{1}{\mathrm{q}_{\mathrm{e}}} \mathrm{t}
$$

Intra-particle diffusion model

$$
q t=\operatorname{kid}^{\frac{1}{2}}+C
$$

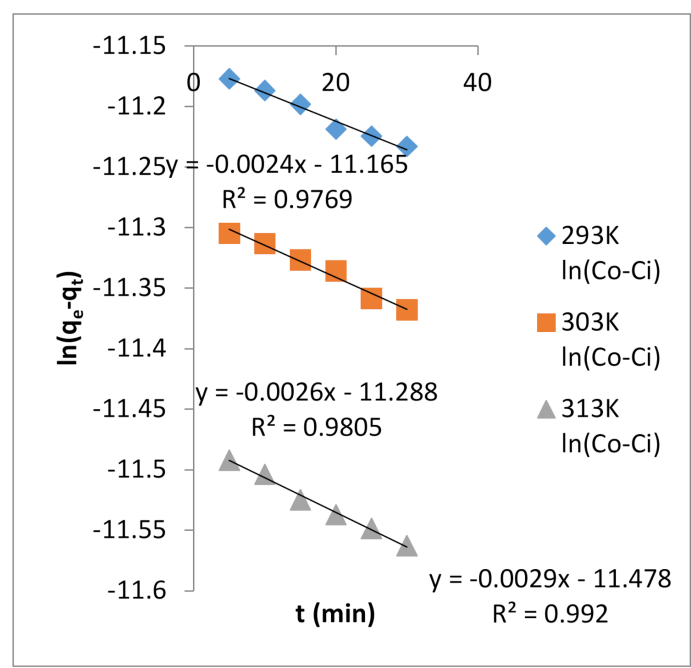

(a)

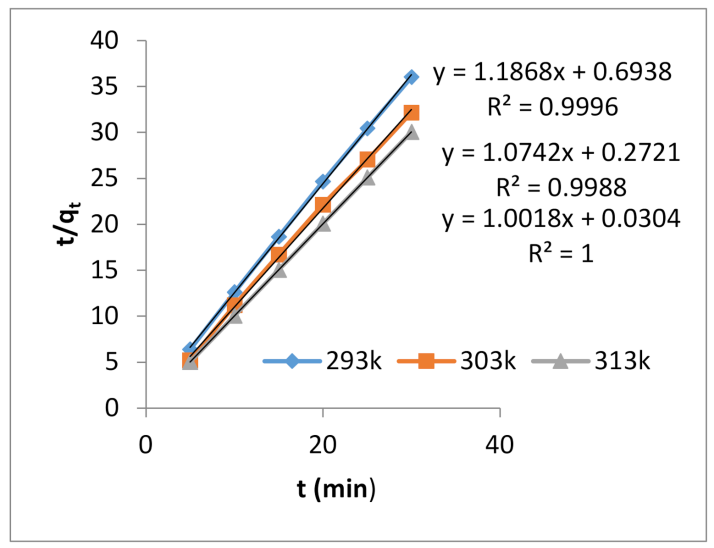

(c)

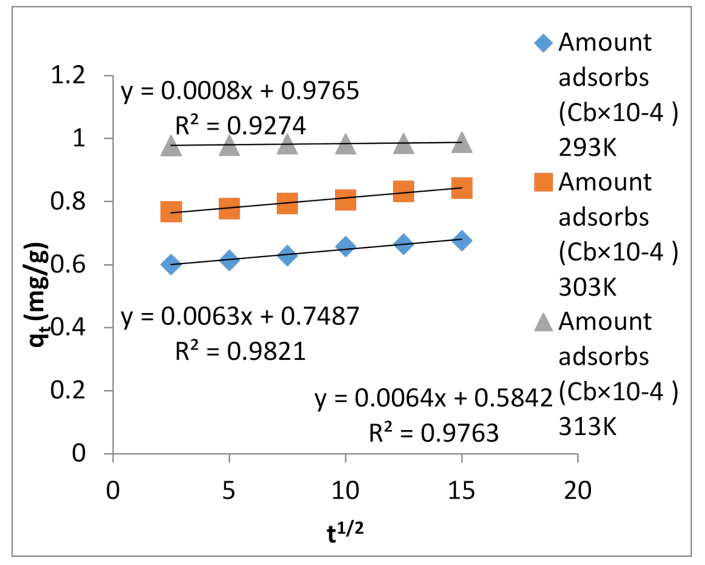

(e)

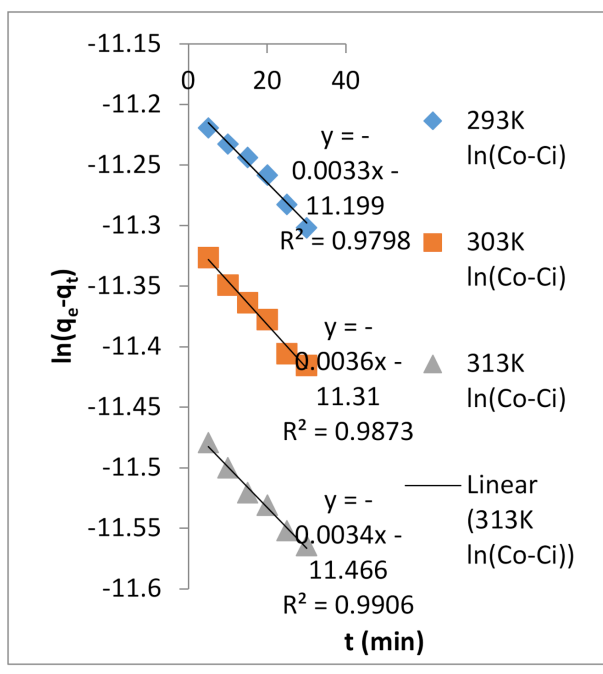

(b)

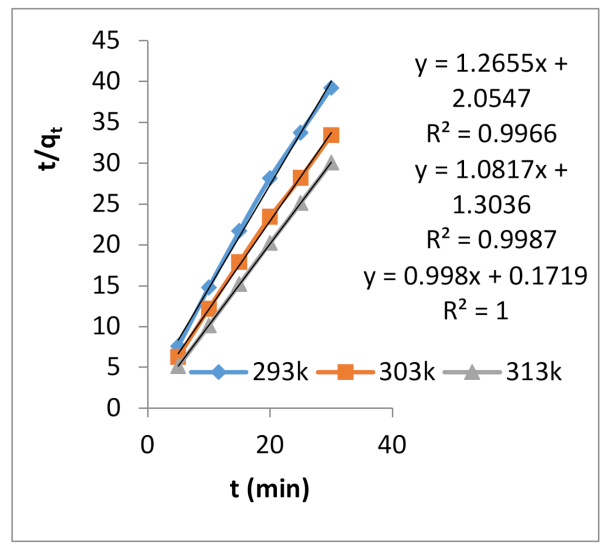

(d)

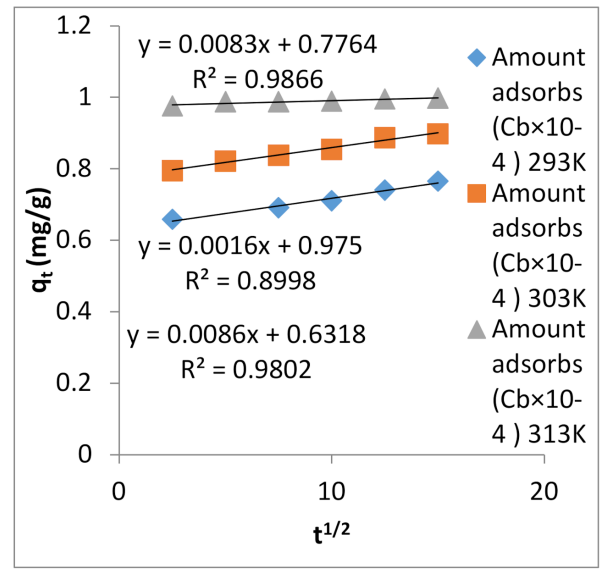

(f)

Figure 9. Kinetic models for RA4: (a) pseudo-first-order kinetics model; (c) pseudo-second-order kinetics model; (e) intraparticle diffusion model. For MB (b) pseudo-first-order kinetics model; (d) pseudo-second-order kinetics model; (f) intraparticle diffusion model. 
The pseudo first and second order kinetics parameters are enumerated in Table 3, while Table 4 shows the intraparticle diffusion model parameters at different temperatures.

Table 3. Kinetic parameters of pseudo-first- and pseudo-second-order for the adsorption of AR4 and MB on AC at $293 \mathrm{~K}, 303 \mathrm{~K}$ and $313 \mathrm{~K}$.

\begin{tabular}{cccccc}
\hline \multicolumn{3}{c}{ Acid Red 4: $\mathbf{K}_{\mathbf{1}}(\mathbf{g} / \mathbf{m o l} / \mathbf{K})$} & \multicolumn{3}{c}{ Methylene Blue: $\mathbf{K}_{\mathbf{2}}$ (g/mol/K) } \\
\hline $\mathbf{2 9 3} \mathbf{K}$ & $\mathbf{3 0 3} \mathbf{K}$ & $\mathbf{3 1 3} \mathbf{~ K}$ & $\mathbf{2 9 3} \mathbf{K}$ & $\mathbf{3 0 3} \mathbf{K}$ & $\mathbf{3 1 3} \mathbf{~}$ \\
\hline 0.0000024 & 0.0000026 & 0.0000029 & $14,312.8$ & $11,584.8$ & $10,093.7$ \\
0.0000033 & 0.0000034 & 0.0000036 & $12,655.5$ & $10,816.7$ & 9987.7 \\
\hline
\end{tabular}

Table 4. Intraparticle model parameters for the adsorption of AR4 and MB on AC.

\begin{tabular}{ccccccc}
\hline \multirow{2}{*}{ Parameters } & \multicolumn{3}{c}{$\begin{array}{c}\text { Adsorption Temperatures } \\
\text { Acid Red 4 }\end{array}$} & \multicolumn{3}{c}{$\begin{array}{c}\text { Adsorption Temperatures } \\
\text { Methylene Blue }\end{array}$} \\
\cline { 2 - 7 } & $\mathbf{2 9 3} \mathbf{K}$ & $\mathbf{3 0 3 ~ K}$ & $\mathbf{3 1 3} \mathbf{K}$ & $\mathbf{2 9 3} \mathbf{K}$ & $\mathbf{3 0 3 ~ K}$ & $\mathbf{3 1 3 ~ K}$ \\
\hline $\mathrm{K}_{\mathrm{ip}}$ & 0.0039 & 0.0053 & 0.0003 & 0.0086 & 0.0083 & 0.0016 \\
Intercept & 0.772 & 0.856 & 0.9936 & 0.6318 & 0.7764 & 0.975 \\
$\mathrm{R}_{2}$ & 0.9786 & 0.9141 & 0.8672 & 0.9802 & 0.9866 & 0.8998 \\
\hline
\end{tabular}

\subsection{Isotherm Studies}

In order to find out the surface properties and affinity of the adsorbent for adsorbates, different isotherm models were applied. The isotherm study is important for the description of how the adsorbates interact with the adsorbent and gives information about the adsorption capacities. The surface of the adsorbent may be occupied by the adsorbate with the formation of monolayer or multilayer. To determine different isotherm parameters, the Langmuir, Freundlich and Temkin models were applied.

\subsubsection{Langmuir Isotherm}

In order to explain the sorption of selected dye onto the prepared adsorbent Langmuir model was used. Basic assumptions of this model are; the sorption process takes place at specific homogenous sites of the adsorbent and it only forms a monolayer on the surface. The linear form of this model can be given as follows [24-26]:

$$
\frac{\mathrm{C}_{\mathrm{e}}}{\mathrm{q}_{\mathrm{e}}}=\frac{\mathrm{C}_{\mathrm{e}}}{\mathrm{Q}_{\mathrm{m}}}+\frac{1}{\mathrm{~K}_{\mathrm{L}} \mathrm{Q}_{\mathrm{m}}}
$$

where $\mathrm{q}_{\mathrm{e}}, \mathrm{C}_{\mathrm{e}}, \mathrm{K}_{\mathrm{L}}$ and $\mathrm{Q}_{\mathrm{m}}$ are the adsorbed amount of dye adsorbed at equilibrium (mg/g), concentration of dye solution at equilibrium (mole/L), Langmuir constant (mole/g) and the maximum adsorption capacity $(\mathrm{mg} / \mathrm{g})$, respectively.

A plot of $\mathrm{C}_{\mathrm{e}} / \mathrm{q}_{\mathrm{e}}$, versus $\mathrm{C}_{\mathrm{e}}$ (from slope and intercept) enabled us to determine the value of $K_{L}$ and $Q_{m}$ (Figure 10a,b) and their values along with the correlation coefficient $R^{2}$ are given in Table 5 . The Langmuir isotherm provided the best correlation coefficient $R^{2}$ value and hence, the best fit for the experimental data. 


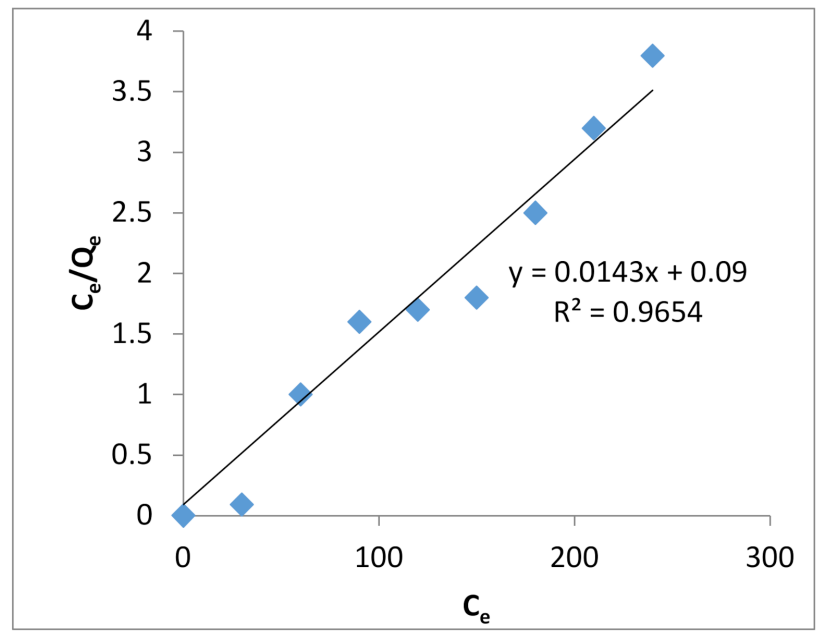

(a)

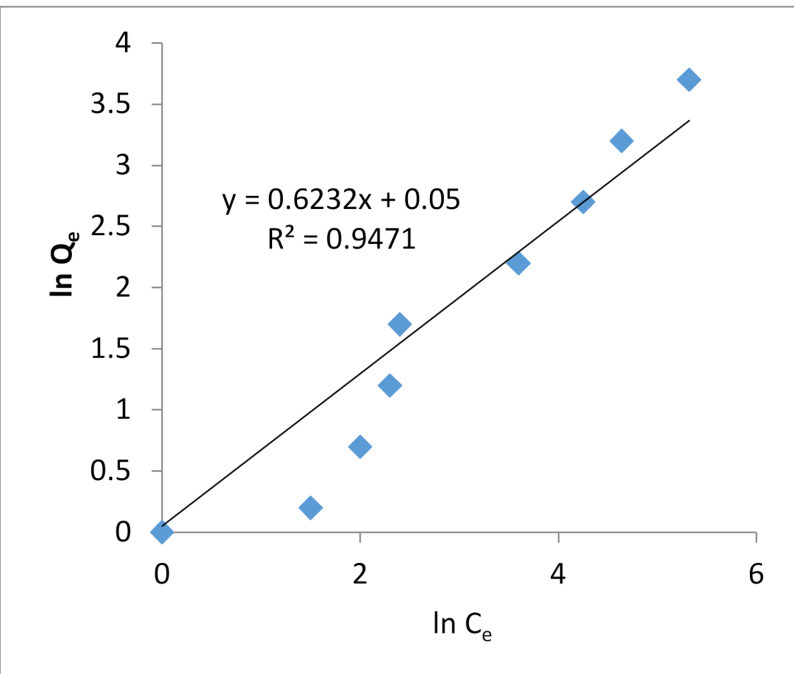

(c)

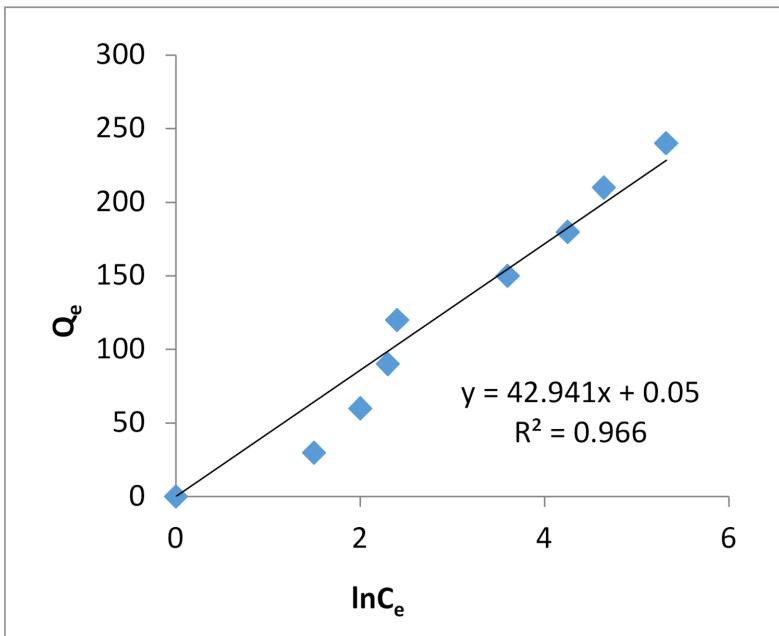

(e)

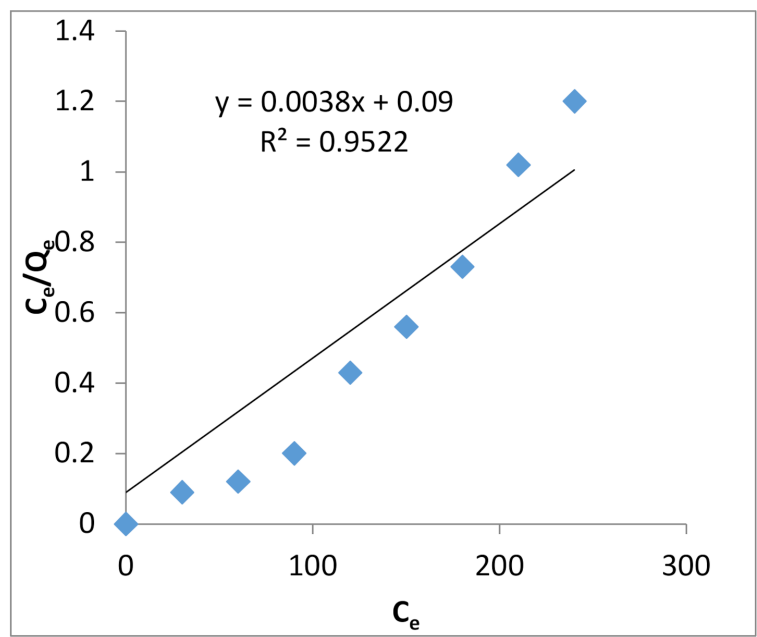

(b)

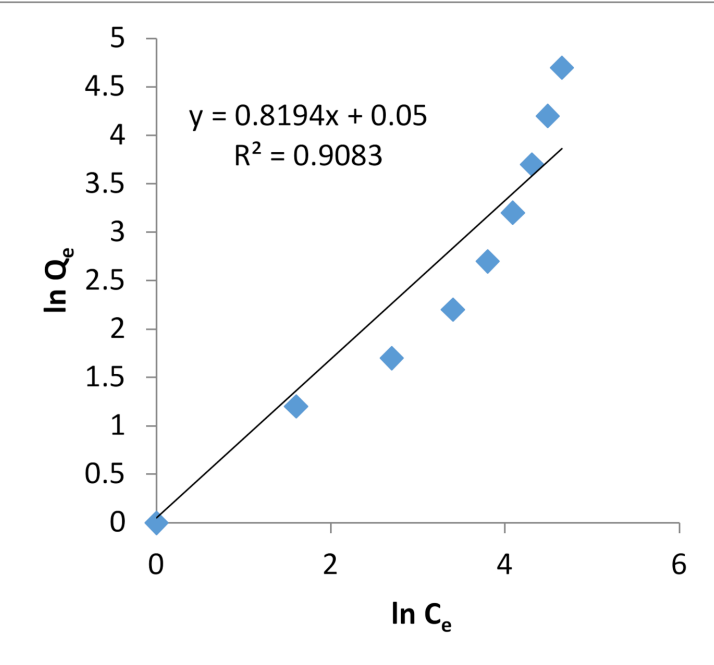

(d)

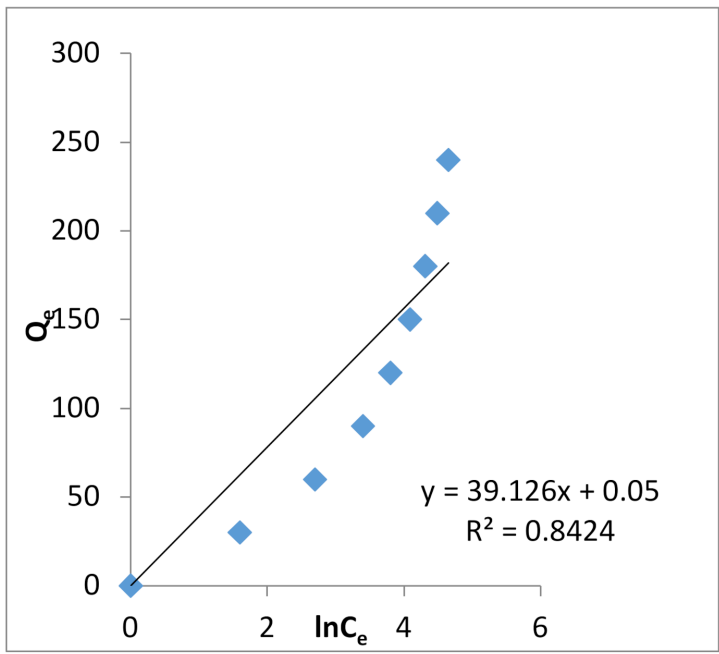

(f)

Figure 10. Langmuir isotherm model for adsorption of (a) Acid Red 4 (b) MB; Freundlich isotherm model for adsorption of (c) acid red 4 (d) MB; Temkin isotherm model for adsorption of (e) acid red 4 (f) Methylene Blue. 
Table 5. Different isotherm parameters for the adsorption of AR4 and MB on prepared AC.

\begin{tabular}{ccc}
\hline Parameter & Langmuir Isotherm for AR4 & Langmuir Isotherm for MB \\
\hline $\mathrm{Q}_{\mathrm{m}}$ & 238.44 & 255.89 \\
$\mathrm{~K}_{\mathrm{L}}$ & 0.014 & 0.003 \\
$\mathrm{R}^{2}$ & 0.957 & 0.886 \\
\hline & Freundlich Isotherm for AR4 & Freundlich Isotherm for MB \\
\hline $\mathrm{K}_{\mathrm{f}}$ & 0.623 & 0.819 \\
$1 / \mathrm{n}$ & 41.25 & 40.273 \\
$\mathrm{R}^{2}$ & 0.908 & 0.839 \\
\hline & Temkin Isotherm for AR4 & Temkin Isotherm for MB \\
\hline $\mathrm{B}_{1}$ & 42.94 & 39.12 \\
$\mathrm{~K}_{\mathrm{T}}$ & 1.063 & 1.053 \\
$\mathrm{R}^{2}$ & 0.953 & 0.803 \\
\hline
\end{tabular}

\subsubsection{Freundlich Isotherm Model}

This model describes non-ideal and reversible adsorption behavior that is not restricted to the formation of a monolayer. This model can be applied to the adsorption on heterogeneous surfaces (multilayer adsorption) and non-uniform distribution of adsorption heat and affinities of the sites over the adsorbent surface. This model can be expressed as follows:

$$
\ln \mathrm{q}_{\mathrm{e}}=\ln \mathrm{Kf}+\frac{1}{\mathrm{n}} \ln \mathrm{C}_{\mathrm{e}}
$$

where $\mathrm{q}_{\mathrm{e}}, \mathrm{C}_{\mathrm{e}}, \mathrm{Kf}$, and $1 / \mathrm{n}$ are the amount of adsorbate adsorbed at equilibrium, equilibrium concentration of dye solution, adsorption capacity at unit concentration and adsorption intensity, respectively.

It should be noted that when $1 / \mathrm{n}=0$, the type of isotherm will be irreversible and when $0<1 / \mathrm{n}<1$ adsorption will be favorable and when $1 / \mathrm{n}>1$, the adsorption process will be unfavorable.

A plot of $\ln \mathrm{q}_{\mathrm{e}}$ versus $\mathrm{C}_{\mathrm{e}}$ enables us to determine the values of $\mathrm{n}$ and $\mathrm{K}_{\mathrm{f}}$ from the slope and intercept (Figure 10c,d). The values of these parameters are given in Table 5.

\subsubsection{Temkin Isotherm Model}

In the linear form this isotherm can be given as follows:

$$
\mathrm{q}_{\mathrm{e}}=\mathrm{B}_{1} \ln \mathrm{K}_{\mathrm{T}}+\mathrm{B}_{1} \ln \mathrm{C}_{\mathrm{e}}
$$

where: $B_{1}$ and $K_{T}$ are heat of adsorption and equilibrium binding constant $(\mathrm{L} / \mathrm{mg})$, respectively. A plot $\mathrm{q}_{\mathrm{e}}$ versus $\ln \mathrm{C}_{\mathrm{e}}$ enable us find out the values of these constants (Figure 10e,f) and their values are given in Table 5. According to Table 5, the $\mathrm{R}^{2}$ values are higher for Langmuir isotherm rather than Freundlich and Temkin models.

\subsection{Thermodynamic Study}

The thermodynamic parameters for the adsorption of AR4 and MB onto prepared AC were calculated using following equations:

$$
\Delta \mathrm{G}^{\circ}=-\mathrm{R} \ln \mathrm{K}_{\mathrm{d}}
$$

where, $\mathrm{K}_{\mathrm{d}}=\frac{\mathrm{Q}_{\mathrm{e}}}{\mathrm{C}_{\mathrm{e}}}$

$$
\ln (\mathrm{Kd})=\frac{\Delta \mathrm{S}^{\circ}}{\mathrm{R}}-\frac{\Delta \mathrm{H}^{\circ}}{\mathrm{RT}}
$$

In these equations, $\Delta \mathrm{G}^{\circ}, \Delta \mathrm{H}^{\circ}$ and $\Delta \mathrm{S}^{\circ}$, are the changes in Gibbs free energy, enthalpy and entropy, respectively. A plot $\ln \mathrm{K}_{\mathrm{d}}$ versus $1 / \mathrm{T}$ enabled us to determine the values of 
$\Delta \mathrm{H}^{\circ}$ and $\Delta \mathrm{S}^{\circ}$, that are usually obtained from slope and intercept of the resultant plot. The values as given in Table 6 .

The values of Gibbs free energy $\left(\Delta G^{\circ}\right)$ were negative at all temperatures indicating the feasibility of the adsorption process and its spontaneous nature. The observed decrease in $\Delta \mathrm{G}^{\circ}$ values with increase in temperature suggests that the higher temperature would facilitate the adsorption process. The negative value of $\Delta \mathrm{H}^{\circ}$ indicates the exothermic nature of the process and the positive value of entropy shows the increase in randomness at the dye/adsorbent interfaces and feasibility of the process.

Table 6. Thermodynamic parameters for adsorption of AR4 and MB onto prepared AC.

\begin{tabular}{|c|c|c|c|c|c|c|}
\hline \multirow{2}{*}{ Sample } & \multirow{2}{*}{$\Delta \mathrm{E}(\mathrm{kJ} / \mathrm{mol})$} & \multirow{2}{*}{$\Delta \mathrm{H}(\mathrm{kJ} / \mathrm{mol})$} & \multirow{2}{*}{$\Delta S(\mathrm{~J} \mathrm{~mol} / \mathrm{K})$} & \multicolumn{3}{|c|}{$\Delta \mathrm{G}(\mathrm{kJ} / \mathrm{mol})$} \\
\hline & & & & $293 \mathrm{~K}$ & $303 \mathrm{~K}$ & $313 \mathrm{~K}$ \\
\hline Acid red 4 & 30.57 & 24.88 & -2843.32 & 950.34 & 945.46 & 942.16 \\
\hline Methylene blue & 3.712 & 1.1927 & -0.329 & 4.6747 & 100.879 & 284.312 \\
\hline
\end{tabular}

\subsection{Adsorption Capacities of Various Adsorbent for Removal of Acidic and MB Dyes Previous} Reported with Our Adsorbent

$\mathrm{AC}$ as an adsorbent is claimed to have high adsorption potential as it has high adsorption capacity as compared to other adsorbents reported in literature [27-32]. Table 7 shows a comparison of present adsorbent with reported ones. Previous studies have emphasized the role of the effects of $\mathrm{pH}$ and parameters on the solubility and performance of nanomaterials, which can be used similarly in following studies [33-37].

Table 7. Comparison of adsorption capacities of various adsorbents for acidic dyes, AR4 and MB with current research work.

\begin{tabular}{cccc}
\hline Dyes & Adsorbent & $\mathbf{Q}_{\max }(\mathbf{m g} / \mathbf{g})$ & Reference \\
\hline Acidic dye & Musa paradisiaca char & 7.003 & {$[27]$} \\
Acidic dye & Activated bleaching earth & 1.2 & {$[28]$} \\
Acidic dye & Aloe barbadensis mill & 3.62 & {$[29]$} \\
Acidic dye & Aloe vera leaves shell & 1.850 & {$[30]$} \\
Acidic dye (AR4) & Activated carbon & 238.44 & Current work \\
MB & Jute fiber carbon & 225.64 & {$[31]$} \\
MB & Almond shell-activated carbon & 1.33 & {$[32]$} \\
MB & Walnut shell-activated carbon & 3.53 & {$[32]$} \\
MB & Hazelnut shell-activated carbon & 8.82 & {$[32]$} \\
MB & Activated carbon & 255.89 & Current work \\
\hline
\end{tabular}

\section{Conclusions}

An efficient adsorbent was prepared from Paulownia tomentosa, which was characterized by surface area analysis, SEM and EDX. The adsorption of acid red 4 and methylene blue was examined by equilibration time and kinetic studies and adsorption isotherm studies at different temperatures $(293,303$, and $313 \mathrm{~K})$ were evaluated using batch experiments. SEM data showed pores of various sizes and shapes on the prepared adsorbent surface where dye residues could favorably be attached. EDX spectrum of prepared AC showed the presence of carbon and oxygen atoms along with other elements. The equilibration time for acid red 4 and methylene blue dye were almost $5 \mathrm{~min}$, indicating the quick adsorption of the selected dyes onto the surface of adsorbent. Langmuir and pseudo- second order models, respectively, fitted well the isotherm and kinetics data. The intraparticle diffusion model showed the adsorption of selected dyes was a diffusion-controlled process.

Author Contributions: Conceptualization, M.Z.; methodology, S.A.; software, M.S.K.; validation, W.B. and I.Z.; formal analysis, M.M.G., J.B., A.K. and N.P.; investigation, S.A.; resources, M.Z.; data curation, S.A.; writing—original draft preparation, S.A.; writing—review and editing, M.S.K., I.Z. 
and M.Z. visualization, M.S.K.; G.D.B.; supervision, M.Z.; project administration, M.Z.; funding acquisition, M.Z. All authors have read and agreed to the published version of the manuscript.

Funding: This research was funded by project nr T190087MIMV and European Commission, MLTKT19481R “Identifying best available technologies for decentralized wastewater treatment and resource recovery for India, SLTKT20427" Sewage sludge treatment from heavy metals, emerging pollutants and recovery of metals by fungi and by project KIK 15392 and 15401 by European Commission.

\section{Institutional Review Board Statement: Not applicable.}

Informed Consent Statement: Not applicable.

Data Availability Statement: The data presented in this study is available on request from the corresponding author.

Acknowledgments: The authors are thankful to HEC, Pakistan and CRL, Peshawar Pakistan for helping in instrumental analysis.

Conflicts of Interest: The authors declare no conflict of interest. The funders had no role in the design of the study; in the collection, analyses, or interpretation of data; in the writing of the manuscript; or in the decision to publish the results.

\section{References}

1. Cechinel, M.A.P.; de Souza, A.A.U. Study of lead (II) adsorption onto activated carbon originating from cow bone. J. Cleaner Prod. 2014, 65, 342-349. [CrossRef]

2. Chiarello, L.M.; Barcellos, I.O.; Spengler, G.; Roza, D.E. Treatment of acidic dyes solutions by adsorption in soybean meal. Acta Scientiarum Technol. 2012, 34, 97-103. [CrossRef]

3. Mezohegyi, G.; van der Zee, F.P.; Font, J.; Fortuny, A.; Fabregat, A. Towards advanced aqueous dye removal processes: A short review on the versatile role of activated carbon. J. Environ. Manag. 2012, 102, 148-164. [CrossRef] [PubMed]

4. Smitha, T.; Thirumalisamy, S.; Manonmani, S. Equilibrium and kinetics study of adsorption of crystal violet onto the peel of Cucumis sativa fruit from aqueous solution. E-J. Chem. 2012, 9. [CrossRef]

5. Ramakrishna, K.R.; Viraraghavan, T. Dye removal using low cost adsorbents. Water Sci. Technol. 1997, 36, 189-196. [CrossRef]

6. Zekker, I.; Artemchuk, O.; Rikmann, E.; Ohimai, K.; Bhowmick, G.D.; Ghangrekar, M.M.; Burlakovs, J.; Tenno, T. Start-up of anammox SBR from non-specific inoculum and process acceleration methods by hydrazine. Water 2021, 13, 350. [CrossRef]

7. Ho, Y.S.; Malarvizhi, R.; Sulochana, N. Equilibrium isotherm studies of methylene blue adsorption onto activated carbon prepared from Delonixregia pods. J. Environ. Prot. Sci. 2009, 3, 111-116.

8. Al-Degs, Y.S.; El-Barghouthi, M.I.; El-Sheikh, A.H.; Gavin, M.W. Effect of solution pH. Dyes Pigm. 2007, 77, 16-23.

9. Arivoli, S.; Sundaravadivelu, M.; Elango, K.P. Removal of basic and acidic dyes from aqueous solution by adsorption on a low cost activated carbon: Kinetic and thermodynamic study. Indian J. Chem. Technol. 2008, 15, 130-139.

10. Parvin, M. Adsorption of Dyes on Activated Carbon from Agricultural Wastes. United Arab Emirates. Univ. 2013. [CrossRef]

11. Pearce, C.I.; Lloyd, J.R.; Guthrie, J.T. The removal of colour from textile wastewater using whole bacterial cells: A review. Dyes Pigm. 2003, 58, 179-196. [CrossRef]

12. Shokoohi, R.; Vatanpoor, V.; Zarrabi, M.; Vatani, A. Adsorption of Acid Red 18 (AR18) by activated carbon from poplar wood-A kinetic and equilibrium study. E-J. Chem. 2010, 7. [CrossRef]

13. Pokhrel, D.; Viraraghavan, T. Treatment of pulp and paper mill wastewater-A review. Sci. Total Environ. 2004, 333, 37-58. [CrossRef] [PubMed]

14. Dabrowski, A. Adsorption-From theory to practice. Adv. Colloid Interface Sci. 2001, 93, 135-224. [CrossRef]

15. El-Bindary, A.A.; Diab, M.A.; Hussien, M.A.; El-Sonbati, A.Z.; Eessa, A.M. Adsorption of Acid Red 57 from aqueous solutions onto polyacrylonitrile/activated carbon composite. Spectrochim. Acta Part A 2014, 124, 70-77. [CrossRef]

16. Dural, M.U.; Cavas, L.; Papageorgiou, S.K.; Katsaros, F.K. Methylene blue adsorption on activated carbon prepared from Posidoniaoceanica (L.) dead leaves: Kinetics and equilibrium studies. Chem. Eng. J. 2011, 168, 77-85. [CrossRef]

17. Dubinin, M.M.; Plavnik, G.M.; Zaverina, E.D. Integrated study of the porous structure of active carbons from carbonized sucrose. Carbon 1964, 2, 261-268. [CrossRef]

18. Ikram, M.; Zahoor, M.; Batiha, G.E.-S. Biodegradation and decolorization of textile dyes by bacterial strains: A biological approach for wastewater treatment. Z. Phys. Chem. 2020. [CrossRef]

19. Khayam, S.M.U.; Zahoor, M.; Khan, E.; Shah, M. Reduction of keto group in drimarene blue by Aspergillus niger; a predominant reason for subsequent decolorization. Fresenius Environ. Bull. 2020, 29, 1397-1410.

20. Ikram, M.; Zahoor, M.; Khan, E.; Khayam, S.M.U. Biodegradation of Novacron Turqueiose (Reactive Blue 21) by Pseudomonas aeruginosa. J. Chem. Soc. Pak. 2020, 42, 737-745.

21. Brunauer, S.; Emmett, P.; Teller, E.J. Adsorption of gases in multi-molecular layers. J. Am. Chem. Soc. 1938, 60, 309-319. [CrossRef] 
22. Tien, C. Adsorption Calculations and Modeling; Scientific Research Publishing Inc.; Butterworth-Heinemann: Washington, DC, USA, 1994; p. 16.

23. Iqbal, Y.; Khan, M.A.; Ihsanullah, N.A. Effect of selected parameters on the adsorption of phenol on activated charcoal. Inter. J. Envi. Studies. 2005, 62, 47-57. [CrossRef]

24. Khan, T.; Chaudhuri, M. Comparison of adsorption behaviour of coconut coir activated carbon and commercial activated carbon for textile dye. WIT Trans. Ecol. Environ. 2011, 148, 105-116.

25. Chang, C.F.; Chang, C.Y.; Chen, K.H.; Tsai, W.T.; Shie, J.L.; Chen, Y.H. Adsorption of naphthalene on zeolite from aqueous solution. J. Colloid Interface Sci. 2004, 277, 29-34. [CrossRef] [PubMed]

26. Khaniabadi, Y.O.; Mohammadi, M.J.; Shegerd, M.; Sadeghi, S.; Saeedi, S.; Basiri, H. Removal of Congo red dye from aqueous solutions by a low-cost adsorbent: Activated carbon prepared from Aloe vera leaves shell. Environ. Health Eng. Manag. J. 2017, 4 , 29-35. [CrossRef]

27. Senthikumaar, S.; Varadarajan, P.R.; Prokodi, K.; Subhuraam, C.V. Adsorption of MB onto jute fiber carbon: Kinetic and equilibrium studies. J. Colloid Interface Sci. 2005, 284, 78-82. [CrossRef]

28. Aygum, A.; Yenisoy-Karakas, S.; Duman, I. Production of granular activated carbon from fruit stones and nutshells and evaluation of their physical, chemical and adsorption properties. Microporous Mesoporous Mater. 2003, 66, 89-95.

29. Tisserat, B.; Joshee, N.; Mahapatra, A.K.; Selling, G.W.; Finkenstadt, V.L. Physical and mechanical properties of extruded poly (lactic acid)-based Paulownia elongate biocomposites. Sci. Verse Sci. Direct Ind. Crops Prod. 2013, 44, 88-96.

30. Deniz, F.; Saygideger, S. D Equilibrium, kinetic and thermodynamic studies of Acid Orange 52 dye biosorption by Paulownia tomentosa Steud. leaf powder as a low-cost natural biosorbent. Bioresour. Technol. 2010, 101, 5137-5143.

31. Tang, Z.Q.; Chen, D.L.; Song, Z.J.; He, Y.C.; Cai, D.T. In vitro induction and identification of tetraploid plants of Paulownia tomentosa. Plant Cell Tiss. Organ Cult. 2012, 102, 213-220. [CrossRef]

32. Li, X.; Qiu, J.; Hu, Y.; Ren, X.; He, L.; Zhao, N.; Ye, T.; Zhao, X. Characterization and comparison of walnuts hells-based activated carbons and their adsorptive properties. Ads. Sci. Tech. 2020, 38, 450-463. [CrossRef]

33. Tenno, T.; Rikmann, E.; Zekker, I.; Tenno, T. Modelling the Solubility of Sparingly Soluble Compounds Depending on their Particles Size. Proc. Est. Acad. Sci. 2018, 67, 300-302. [CrossRef]

34. Zekker, I.; Tenno, T.; Selberg, A.; Uiga, K. Dissolution Modeling and Experimental Measurement of CaS- $\mathrm{H}_{2} \mathrm{O}$ Binary System. Chin. J. Chem. 2011, 29, 2327-2336. [CrossRef]

35. Tenno, T.; Rikmann, E.; Uiga, K.; Zekker, I.; Mashirin, A.; Tenno, T. A Novel Proton Transfer Model of the Closed Equilibrium System $\mathrm{H}_{2} \mathrm{O}-\mathrm{CO}_{2}-\mathrm{CaCO}_{3}-\mathrm{NH}_{X}$. Proc. Est. Acad. Sci. 2018, 4017, 2. [CrossRef]

36. Tenno, T.; Uiga, K.; Mashirin, A.; Zekker, I.; Rikmann, E. Modeling Closed Equilibrium Systems of $\mathrm{H}_{2} \mathrm{O}-\mathrm{Dissolved} \mathrm{CO}_{2}$-Solid $\mathrm{CaCO}_{3}$. J. Phys. Chem. A. 2017, 121, 3094-3100. [CrossRef]

37. Uiga, K.; Tenno, T.; Zekker, I.; Tenno, T. Dissolution modeling and potentiometric measurements of the $\mathrm{SrS}_{-} \mathrm{H}_{2} \mathrm{O}-\mathrm{gas}$ system at normal pressure and temperature at salt concentrations of 0.125-2.924 mM. J. Sulf. Chem. 2011, 32, 137-149. [CrossRef] 